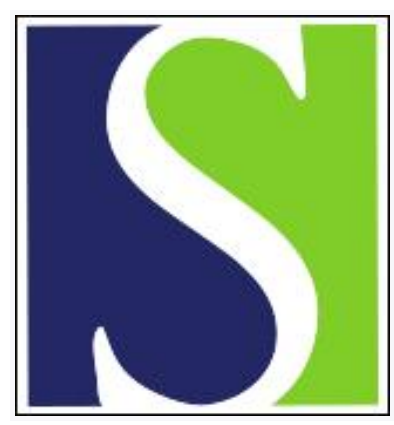

Scand J Work Environ Health 1995;21(1):36-42

https://doi.org/10.5271/sjweh.6

Issue date: Feb 1995

Single-strand breaks in deoxyribonucleic acid in fire fighters accidentally exposed to o-nitroanisole and other chemicals

by Hengstler JG, Fuchs J, Bolm-Audorff U, Meyer S, Oesch F

Key terms: acute toxicity; biomonitoring; dna single-strand breaks; fire fighter; human mononuclear blood cells; o-nitroanisole

This article in PubMed: www.ncbi.nlm.nih.gov/pubmed/7784863

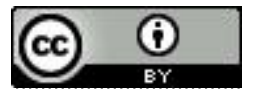




\title{
Single-strand breaks in deoxyribonucleic acid in fire fighters accidentally exposed to o-nitroanisole and other chemicals
}

\author{
by Jan Georg Hengstler, MD, ${ }^{1}$ Jürgen Fuchs, PhD, ${ }^{1}$ Ulrich Bolm-Audorff, MD, ${ }^{2}$ \\ Sieglinde Meyer, MD, ${ }^{3}$ Franz Oesch, PhD'
}

\begin{abstract}
Hengstler JG, Fuchs J, Bolm-Audorff U, Meyer S, Oesch F. Single-strand breaks in deoxyribonucleic acid in fire fighters accidentally exposed to o-nitroanisole and other chemicals. Scand $J$ Work Environ Health 1995; $21: 36-42$

Objectives The aim of the study was to detect single-strand breaks in deoxyribonucleic acid (DNA) in mononuclear blood cells of fire fighters exposed to o-nitroanisole and other substances released into the environment during an accident in a chemical plant.

Methods The level of DNA single-strand breaks in mononuclear blood cells was detected by alkaline elution. The results were compared for 16 fire fighters who worked in a contaminated area for about $8 \mathrm{~h}$ and two reference groups (one of fire fighters who had not worked in the contaminated area, group I, and one of persons without any apparent occupational exposure to genotoxic substances, group II).

Results The mean normalized elution rate ( $\mathrm{nER}$ ) $19 \mathrm{~d}$ after the accident was slightly but statistically significantly $(\mathrm{P}<0.05)$ higher for the exposed fire fighters [mean $1.48 \pm 95 \%$ confidence interval $(95 \% \mathrm{CI})$ 0.21 ] than for reference group I (mean $1.21 \pm 95 \% \mathrm{CI} 0.21$ ) or reference group II (mean $1.17 \pm 95 \% \mathrm{CI} 0.18$ ). No statistically significant difference was found between reference groups I and II. Another analysis was performed three months after the first. The level of DNA single-strand breaks (mean nER $1.12 \pm 95 \% \mathrm{CI} 0.11$ ) was no longer increased in comparison with the levels of the reference groups.

Conclusions DNA single-strand breaks were increased in fire fighters exposed to $o$-nitroanisole and other substances. In comparison with the extent of DNA strand breaks found in other occupational groups the increase was only moderate. The observed decrease in DNA single-strand breaks to the reference level in exposed fire fighters three months later suggests a DNA repair mechanism for DNA single-strand breaks caused by o-nitroanisole.
\end{abstract}

Key ferms acute toxicity, biomonitoring, DNA single-strand breaks, fire fighters, human mononuclear blood cells, o-nitroanisole.

During an accident in a chemical factory in Germany (22 February 1993) about $10 \mathrm{t}$ of a vaporous mixture of substances was released from a methoxylation plant. The solid parts of the released vapor $(3.5 \mathrm{t})$ precipitated in the area of the plant and in a suburb across the river Main (table 1). In the breathing air of this suburb, $o$-nitroanisole concentrations of up to $18 \mu \mathrm{g} \cdot \mathrm{m}^{-3}$ were detected. In one street of the contaminated suburb 180-200 mg of $o$-nitroanisole precipitated per square meter of land. In a more distant street at the border of the contaminated area $5-10 \mathrm{mg}$ of $o$-nitroanisole was detected per square meter of land. During the next few days this precipitate was removed mechanically with brushes, high-pressure cleaning machines, and so forth by workers from the chemical plant and by fire fighters. The fire fighters did not use protective masks or protective clothing at the beginning of their work in the contaminated area, because significant exposure levels were not expected. $o$-Nitroanisole, the most important substance emitted during the accident, is known to be mutagenic in the Ames test (1) and has caused cancer in experimental animals (2). Exposure to o-nitroanisole can occur through inhalation, penetration of the skin (3), and ingestion. Several other chemicals released during the accident, such as $o$-anisidine and $o$-chloronitrobenzene, are also considered genotoxic (4-8).

In this study we used a modified alkaline elution method to investigate DNA single-strand breaks in mononuclear blood cells of fire fighters who were working in the contaminated area. By alkaline elution the genotoxic

1 Institute of Toxicology, University of Mainz, Mainz, Germany.

2 Ministry of Women, Work, and Social Welfare, Division of Occupational Medicine, Wiesbaden, Germany.

3 Medical Service Frankfurt/Main for Fire Fighters, Frankfurt, Germany.

Reprint requests to: Dr JG Hengstler, Institute of Toxicology, University of Mainz, Obere Zahlbacher Str 67, D 55131 Mainz, Germany. 
effect of all substances inducing DNA single-strand breaks or adducts which render the DNA alkali labile can be detected. Therefore, it is not necessary to adapt the method for individual substances, and also the effect of unknown genotoxins can be determined. Therefore the alkaline elution method is suitable for biomonitoring the effect of mixtures of various chemicals. DNA singlestrand breaks or alkali labile sites are known to be induced by the majority of genotoxic animal carcinogens. Sina et al (8) used the alkaline elution assay for detecting DNA single-strand breaks in rat hepatocytes and reported that the assay had a high potential to identify genotoxic carcinogens. In humans, DNA single-strand breaks have previously been used as an indicator of genotoxic exposure in a few cases. Walles et al (9) and MäkiPaakkanen et al (10) detected DNA single-strand breaks to biomonitor human exposure to styrene using the DNA unwinding method or the alkaline elution technique (11). Recently we described a modified alkaline elution procedure for biomonitoring DNA single-strand breaks in mononuclear blood cells of humans exposed to genotoxic substances $(12-14)$. In the present study we have compared the number of DNA single-strand breaks in fire fighters accidently exposed to $o$-nitroanisole and several other chemicals with those of a matched group of fire fighters who were not in the contaminated area (reference group I) and with other individuals without any apparent occupational exposure to genotoxic substances (reference group II).

\section{Subjects and methods}

\section{Subjects}

The exposed fire fighters were healthy men who had been exposed to a mixture of substances (table 1) released during an accident in a chemical plant. They had worked in the contaminated area for about $8 \mathrm{~h}$. One fire fighter had been exposed for $40 \mathrm{~h}$. Detailed information on the duties carried out in the contaminated area is given in table 2. During the exposure, none of the fire fighters had worn protective clothing, nor had other safety provisions been applied.

Reference group I consisted of unexposed fire fighters who had not worked in the contaminated area. They were matched with the exposed fire fighters for age, alcohol consumption, town of residence, and the number of cigarettes smoked in the group of smokers. The exposed fire fighters were still in training and had not yet been involved in fire fighting, with the exception of subject F2. The firefighting activity of this subject and of the unexposed fire fighters (reference group I) was relatively low (less than two fires per month). Another group of referents (group II) was constructed of male students

and office employees without any apparent occupational exposure to genotoxic substances.

An interviewer-administered questionnaire was used to collect data from each subject prior to the collection of the blood samples. The questionnaire included information on cigarette smoking (number of cigarettes currently smoked per day, lifetime smoking history), age, health history, intake of alcohol and drugs, exposure to putative carcinogens or ionizing radiation, occupation, and length of occupation and occupational exposure. The fire fighters were asked to give the time they had worked in the contaminated area and the duties they had carried out, use of protective clothing, and complaints related to their exposure in the contaminated area. The age, smoking habits, and occupation of the referents and fire fighters, as well as the complaints of the fire fighters in relation to exposure and their duty carried out in the contaminated region are summarized in tables 2-4. The exposed fire fighters and reference groups I and II were similar with respect to the distributions of age and the number of cigarettes smoked in the group of smokers. Alcohol consumption was similar for the exposed [4.2 (SD 2.2) $\mathrm{g}$ of alcohol a day] and unexposed [5.0 (SD 2.5) g a day] fire fighters but higher for reference group II [10.9 (SD 4.5) $\mathrm{g}$ a day]. None of the subjects used drugs or had apparently been exposed to genotoxic substances (besides the exposure studied) or ionizing radiation.

Table 1. Substances precipitated during the accident in the chemical plant, given in mass percentage. A total of $3.5 \mathrm{t}$ precipitated.

\begin{tabular}{lc}
\hline Substance & Percentage \\
\hline o-Nitroanisole & 27.8 \\
Sodium formate & 14.0 \\
Sodium chloride & 11.6 \\
Water & 12.2 \\
2,2'-Dichloroazoxybenzene & 7.8 \\
2,2'-Dichloroazobenzene & 4.9 \\
Dimethoxyazoxybenzene & 4.2 \\
o-Nitrophenol & 3.5 \\
Chloromethoxyazoxybenzene & 2.5 \\
0-Chloroaniline & 1.5 \\
0-Chloronitrobenzene & 1.4 \\
Methanol & 1.1 \\
Sodium carbonate & 0.9 \\
o-Anisidine & 0.7 \\
2,2'-Chloronitrodiphenylamine & 0.7 \\
Chloromethoxyazobenzene & 0.6 \\
Nitrobenzene & 0.3 \\
Chloroazoxybenzene & 0.3 \\
Chlorohydroxyazobenzene & 0.3 \\
Substituted biphenyl $\left(\mathrm{C}_{12} \mathrm{H}_{9} \mathrm{O}_{3} \mathrm{~N}_{2} \mathrm{Cl}\right)$ & 0.3 \\
Substituted diphenylamine $\left(\mathrm{C}_{12} \mathrm{H}_{9} \mathrm{~N}_{2} \mathrm{Cl}\right)$ & 0.3 \\
Sodium nitrite & 0.3 \\
Substituted diphenylamine $\left(\mathrm{C}_{12} \mathrm{H}_{11} \mathrm{ON}{ }_{2} \mathrm{Cl}\right)$ & 0.2 \\
o-Chloroanisole & 0.1 \\
Phenazine & 0.1 \\
Sodium hydroxide & 0.1 \\
Dimethoxyazobenzene & 0.1 \\
Inorganic contaminants $\left(\mathrm{rust}_{3} \mathrm{salts}\right)$ & 2.0 \\
\hline
\end{tabular}


Table 2. Age, smoking habits, normalized elution rates, individual duty carried out in the contaminated region, and exposurerelated complaints of the fire fighters exposed to o-nitroanisole and other chemicals. The measurements were performed $19 \mathrm{~d}$ after the exposure (first analysis) and $88 \mathrm{~d}$ later (second analysis). The time of exposure was about $8 \mathrm{~h}$ for all of the fire fighters except F2, who was exposed for $40 \mathrm{~h}$. None of the fire fighters wore protective clothing, except F16 who wore gloves. (NT=not tested)

\begin{tabular}{|c|c|c|c|c|c|c|}
\hline \multirow{2}{*}{$\begin{array}{l}\text { Code } \\
\text { number of } \\
\text { fire fighter }\end{array}$} & \multirow[t]{2}{*}{$\begin{array}{c}\text { Age } \\
\text { (years) }\end{array}$} & \multirow[t]{2}{*}{$\begin{array}{l}\text { Cigarettes } \\
\text { per day }\end{array}$} & \multicolumn{2}{|c|}{$\begin{array}{l}\text { Normalized elution } \\
\text { rates }\end{array}$} & \multirow[t]{2}{*}{ Duty carried out } & \multirow[t]{2}{*}{$\begin{array}{l}\text { Complaints related } \\
\text { to exposure }\end{array}$} \\
\hline & & & $\begin{array}{c}\text { First } \\
\text { analysis }\end{array}$ & $\begin{array}{l}\text { Second } \\
\text { analysis }\end{array}$ & & \\
\hline $\mathrm{F} 1$ & 24 & - & 1.31 & 1.31 & $\begin{array}{l}\text { Reconnaissance of the } \\
\text { contaminated region }\end{array}$ & $\begin{array}{l}\text { Skin rash around mouth } \\
\text { and nose for one day }\end{array}$ \\
\hline $\mathrm{F} 2$ & 46 & - & 2.26 & 0.90 & Reconnaissance & $\begin{array}{l}\text { Nose bleeding for one day, } \\
\text { chapped lip }\end{array}$ \\
\hline F3 & 30 & - & 2.03 & 1.10 & $\begin{array}{l}\text { Reconnaissance, } \\
\text { distribution of } \\
\text { leaflets }\end{array}$ & Dry cough for two days \\
\hline $\mathrm{F} 4$ & 23 & - & 1.22 & 0.67 & $\begin{array}{l}\text { Reconnaissance, } \\
\text { distribution of } \\
\text { leaflets }\end{array}$ & $\begin{array}{l}\text { Headache for one day, } \\
\text { burning of the eyes } \\
\text { for one day }\end{array}$ \\
\hline $\mathrm{F} 5$ & 31 & 15 & 0.80 & 1.13 & Reconnaissance & $\begin{array}{l}\text { Nose bleeding for one day, } \\
\text { headache for seven days }\end{array}$ \\
\hline F6 & 32 & 20 & 1.34 & 1.02 & Distribution of leaflets & None \\
\hline F7 & 30 & - & 2.13 & 1.14 & Reconnaissance & $\begin{array}{l}\text { Burning of the eyes } \\
\text { for one day }\end{array}$ \\
\hline F8 & 30 & 15 & 1.35 & 1.11 & $\begin{array}{l}\text { Truck driver, loading } \\
\text { of contaminated } \\
\text { material }\end{array}$ & $\begin{array}{l}\text { Nose bleeding, skin rash } \\
\text { on the neck, headache for } \\
\text { one day, influenzal } \\
\text { infection after exposure }\end{array}$ \\
\hline $\mathrm{Fg}$ & 29 & 8 & NT & 0.96 & $\begin{array}{l}\text { Commanding officer } \\
\text { of fire fighting unit }\end{array}$ & $\begin{array}{l}\text { Irritation of the mouth } \\
\text { mucous membrane, burning } \\
\text { of the eyes for one day }\end{array}$ \\
\hline $\mathrm{F} 10$ & 28 & - & 1.31 & 0.99 & Reconnaissance & None \\
\hline $\mathrm{F} 11$ & 28 & 10 & NT & 1.26 & Reconnaissance & $\begin{array}{l}\text { Irritation of the upper } \\
\text { respiratory tract for one day }\end{array}$ \\
\hline F12 & 25 & 一 & 1.39 & 1.32 & Reconnaissance & None \\
\hline $\mathrm{F} 13$ & 26 & 15 & 1.17 & 0.94 & Reconnaissance & $\begin{array}{l}\text { Irritation of the upper } \\
\text { respiratory tract for one day }\end{array}$ \\
\hline $\mathrm{F} 14$ & 22 & - & 1.59 & 1.67 & Reconnaissance & None \\
\hline F15 & 24 & - & 1.47 & 1.30 & Reconnaissance & Headache for one day \\
\hline F16 & 33 & - & 1.29 & 1.03 & $\begin{array}{l}\text { Reconnaissance, } \\
\text { cleaning of the } \\
\text { railing of a bridge } \\
\text { for one hour }\end{array}$ & $\begin{array}{l}\text { Skin rash on the neck and } \\
\text { back for one day, irritation } \\
\text { of the upper respiratory } \\
\text { tract for one day }\end{array}$ \\
\hline \multicolumn{7}{|l|}{ Complete group } \\
\hline $\begin{array}{l}\text { Mean value } \\
95 \% \text { confidence }\end{array}$ & 28.8 & 5.2 & 1.48 & 1.12 & & \\
\hline interval & 2.8 & 3.6 & 0.21 & 0.11 & & \\
\hline \multicolumn{7}{|l|}{ Nonsmokers } \\
\hline $\begin{array}{l}\text { Mean value } \\
95 \% \text { confidence }\end{array}$ & 28.5 & - & 1.60 & 1.14 & & \\
\hline interval & 4.4 & - & 0.24 & 0.17 & & \\
\hline \multicolumn{7}{|l|}{ Smokers } \\
\hline $\begin{array}{l}\text { Mean value } \\
95 \% \text { confidence }\end{array}$ & 29.3 & 13.8 & 1.17 & 1.07 & & \\
\hline interval & 1.7 & 3.4 & 0.25 & 0.10 & & \\
\hline
\end{tabular}

\section{Alkaline elution}

Blood samples for the determination of DNA singlestrand breaks were collected from the subjects $19 \mathrm{~d}$ after the exposure and also three months later. Venous blood,
$20 \mathrm{ml}$ per person, was taken into heparinized tubes, transported to the laboratory on ice, and processed within $3 \mathrm{~h}$. Mononuclear blood cells were isolated by metrizoateFicoll centrifugation according to Boyum (15). The alka- 
Table 3. Smoking habits, age, and normalized elution rates of the unexposed fire fighters (reference group I).

\begin{tabular}{|c|c|c|c|}
\hline $\begin{array}{l}\text { Gode number } \\
\text { of fire fighter }\end{array}$ & $\begin{array}{c}\text { Age } \\
\text { (years) }\end{array}$ & $\begin{array}{l}\text { Cigarettes } \\
\text { per day }\end{array}$ & $\begin{array}{l}\text { Normalized } \\
\text { elution } \\
\text { rates }\end{array}$ \\
\hline $\begin{array}{l}\text { FC1 } \\
\text { FC2 } \\
\text { FC3 } \\
\text { FC4 } \\
\text { FC5 } \\
\text { FC6 } \\
\text { FC7 } \\
\text { FC8 } \\
\text { FC9 } \\
\text { FC10 } \\
\text { FC11 } \\
\text { FC12 } \\
\text { FC13 } \\
\text { FC14 } \\
\text { FC15 } \\
\text { FC16 } \\
\text { FC17 } \\
\text { FC18 } \\
\text { FC19 }\end{array}$ & $\begin{array}{l}26 \\
24 \\
34 \\
23 \\
24 \\
29 \\
27 \\
26 \\
29 \\
27 \\
24 \\
29 \\
26 \\
28 \\
21 \\
27 \\
26 \\
26 \\
23\end{array}$ & $\begin{array}{l}15 \\
- \\
- \\
- \\
- \\
- \\
- \\
\frac{20}{-} \\
-18 \\
13 \\
15 \\
- \\
-\end{array}$ & $\begin{array}{l}1.08 \\
1.40 \\
2.17 \\
0.49 \\
1.32 \\
1.11 \\
1.56 \\
0.99 \\
1.31 \\
1.20 \\
2.28 \\
1.02 \\
0.43 \\
1.14 \\
0.88 \\
1.15 \\
0.89 \\
1.36 \\
1.14\end{array}$ \\
\hline \multicolumn{4}{|l|}{ Complete group } \\
\hline $\begin{array}{l}\text { Mean value } \\
95 \% \text { confidence } \\
\text { interval }\end{array}$ & $\begin{array}{l}26.1 \\
1.3\end{array}$ & $\begin{array}{l}4.3 \\
3.4\end{array}$ & $\begin{array}{l}1.21 \\
0.21\end{array}$ \\
\hline \multicolumn{4}{|l|}{ Nonsmokers } \\
\hline $\begin{array}{l}\text { Mean value } \\
95 \% \text { confidence } \\
\text { interval }\end{array}$ & $\begin{array}{r}26.4 \\
1.6\end{array}$ & - & $\begin{array}{l}1.29 \\
0.25\end{array}$ \\
\hline \multicolumn{4}{|l|}{ Smokers } \\
\hline $\begin{array}{l}\text { Mean value } \\
95 \% \text { confidence } \\
\text { interval }\end{array}$ & $\begin{array}{r}25.8 \\
2.6\end{array}$ & $\begin{array}{r}16.2 \\
2.4\end{array}$ & $\begin{array}{l}0.97 \\
0.30\end{array}$ \\
\hline
\end{tabular}

line elution method of Kohn et al (16) was employed with some modifications. A suspension of two million mononuclear blood cells in $1 \mathrm{ml}$ of cold phosphate buffered saline was poured onto a polycarbonate filter $(\mathrm{Nu}-$ cleopore, Tübingen, Germany, $25 \mathrm{~mm}$ diameter, $2 \mu \mathrm{m}$ pore size). The cells were lysed with $3 \mathrm{ml}$ of a solution of $10 \mathrm{mM}$ ethylenediaminetetraacetic acid (EDTA), 0.5\% Triton $\mathrm{X}-100$, and $2 \mathrm{M}$ sodium chloride ( $\mathrm{NaCl}$ ) (adjusted to $\mathrm{pH} 10$ with sodium hydroxide) for $60 \mathrm{~min}$. The lysed cells were washed with $4.5 \mathrm{ml}$ of $10 \mathrm{mM}$ EDTA (adjusted to $\mathrm{pH} 10$ with sodium hydroxide) using a flow rate of $3 \mathrm{ml} \cdot \mathrm{h}^{-1}$ for $90 \mathrm{~min}$. Before the sampling of the eluted DNA was started, one fraction equal to the volume of the tube $(0.25 \mathrm{ml})$ was discarded. The elution was performed at $4^{\circ} \mathrm{C}$ in the dark using a $5 \mathrm{M} \mathrm{NaCl}, 2 \mathrm{mM}$ EDTA solution adjusted to $\mathrm{pH} 12.6$ with sodium hydroxide. With a pump speed of $1.5 \mathrm{ml} \cdot \mathrm{h}^{-1}$, the eluate was collected over a period of $10 \mathrm{~h}$. The filters were removed and sonicated in a $15-\mathrm{ml}$ elution solution for $2 \times 15 \mathrm{~min}$ (filter fraction). Quantification of the DNA was performed as described earlier (13). For standardization, DNA of untreated V79 cells, a Chinese hamster lung
Table 4. Age, smoking habits, occupation, and normalized elution rates of persons without any apparent genotoxic occupational exposure (reference group II).

\begin{tabular}{|c|c|c|c|c|}
\hline $\begin{array}{l}\text { Code number } \\
\text { of referent }\end{array}$ & $\begin{array}{c}\text { Age } \\
\text { (years) }\end{array}$ & $\begin{array}{l}\text { Ciga- } \\
\text { rettes } \\
\text { per day }\end{array}$ & $\begin{array}{l}\text { Occupa- } \\
\text { tion }\end{array}$ & $\begin{array}{l}\text { Normalized } \\
\text { elution } \\
\text { rate }\end{array}$ \\
\hline 1 & 24 & 20 & Student & 1.00 \\
\hline 2 & 26 & 20 & Student & 2.11 \\
\hline 3 & 25 & 15 & Student & 0.94 \\
\hline 4 & 25 & - & Student & 0.82 \\
\hline 5 & 29 & 18 & Student & 0.91 \\
\hline 6 & 40 & - & Office clerk & 0.95 \\
\hline 7 & 26 & 20 & Student & 1.23 \\
\hline 8 & 22 & 10 & Student & 0.69 \\
\hline 9 & 26 & 20 & Student & 1.36 \\
\hline 10 & 26 & - & Student & 1.55 \\
\hline 11 & 42 & - & Office clerk & 1.15 \\
\hline 12 & 28 & - & Student & 1.27 \\
\hline 13 & 28 & 15 & Student & 0.93 \\
\hline 14 & 26 & - & Student & 1.72 \\
\hline 15 & 23 & - & Student & 1.84 \\
\hline 16 & 52 & - & Nurse & 1.20 \\
\hline 17 & 28 & - & Nurse & 0.75 \\
\hline 18 & 22 & - & Student & 0.55 \\
\hline 19 & 22 & - & Student & 0.37 \\
\hline 20 & 50 & 20 & Cleaner & 0.22 \\
\hline 21 & 28 & 20 & Student & 1.42 \\
\hline 22 & 27 & - & Student & 2.10 \\
\hline 23 & 25 & - & Student & 1.04 \\
\hline 24 & 28 & - & Student & 1.18 \\
\hline 25 & 28 & 5 & Student & 1.61 \\
\hline 26 & 24 & - & Student & 1.26 \\
\hline 27 & 27 & - & Student & 0.78 \\
\hline 28 & 25 & 3 & Student & 1.68 \\
\hline \multicolumn{5}{|l|}{ Complete group } \\
\hline \multirow{2}{*}{$\begin{array}{l}\text { Mean value } \\
95 \% \text { confidence } \\
\text { interval }\end{array}$} & 28.6 & 6.6 & & 1.17 \\
\hline & 2.9 & 3.3 & & 0.18 \\
\hline \multicolumn{5}{|l|}{ Nonsmokers } \\
\hline \multirow{2}{*}{$\begin{array}{l}\text { Mean value } \\
95 \% \text { confidence } \\
\text { interval }\end{array}$} & 29.1 & - & & 1.16 \\
\hline & 41 & - & & 0.23 \\
\hline \multicolumn{5}{|l|}{ Smokers } \\
\hline \multirow{3}{*}{$\begin{array}{l}\text { Mean value } \\
95 \% \text { confidence } \\
\text { interval }\end{array}$} & 28.1 & 15.5 & & 1.18 \\
\hline & & & & \\
\hline & 4.1 & 3.5 & & 0.28 \\
\hline
\end{tabular}

fibroblast cell line, was eluted simultaneously in every run on separate filters. V79 cells were cultured as described earlier (13). DNA concentrations of the eluted fractions, and of the filter fractions, were determined in triplicate. The elution rate was calculated as $\left(\log _{10} \mathrm{R}\right) \cdot 0.1 \mathrm{~h}^{-1}$, in which $\mathrm{R}$ represents the fraction of DNA remaining on the filter after $10 \mathrm{~h}$ of elution. The normalized elution rate is expressed as the ratio of the elution rate of test cell DNA to the elution rate of V79 DNA. The DNA of the peripheral mononuclear blood cells, as well as the DNA of the V79 cells, was eluted on four separate filters each, and the mean values of these four elution runs were calculated. Samples from the exposed fire fighters, reference group I, and reference group II were analyzed simultaneously, and samples from a 
constant number of persons from each of the three groups were analyzed per elution run.

The U-test, according to Wilcoxon, Whitney, and Mann (two-sided) was applied to evaluate the statistical significance of differences in unpaired data, and Wilcoxon's signed rank test was used to evaluate paired data. The $95 \%$ confidence intervals $(95 \% \mathrm{CI})$ were calculated as $1.96 \cdot \mathrm{SD} / \mathrm{n}^{0.5}$, where $\mathrm{SD}$ represents the standard deviation and $n$ the number of persons. The mean values $\pm 95 \%$ confidence intervals are given. The statistical significance of the correlation coefficients of the linear regression was evaluated with the use of the t-statistic.

\section{Results}

The mean normalized elution rate of the fire fighters working in the contaminated area was $1.48( \pm 95 \% \mathrm{Cl}$ 0.21 ) in the first measurement, which was performed $19 \mathrm{~d}$ after the exposure (table 2). For the unexposed fire fighters (reference group I) living in the same town a mean normalized elution rate of 1.21 ( $\pm 95 \%$ CI 0.21 ) was obtained (table 3 ). The difference between the exposed fire fighters and reference group I was statistically significant $(\mathrm{P}<0.05$, U-test). The mean normalized elution rate of reference group II was 1.17 ( $\pm 95 \% \mathrm{CI} 0.18$ ) (table 4 ), and it did not differ statistically significantly from that of reference group I, but was statistically significantly smaller than the mean normalized elution rate of fire fighters exposed to o-nitroanisole $(\mathrm{P}<0.05$, U-test).

Another analysis of DNA single-strand breaks was performed for the same exposed fire fighters $88 \mathrm{~d}$ after the first analysis (table 2 ). The mean normalized elution rate in this investigation was $1.12( \pm 95 \% \mathrm{CI} 0.11)$, which was similar to that obtained for the reference groups and was statistically significantly smaller than the mean elution rate in the first analysis $(\mathrm{P}<0.01$, Wilcoxon's signed rank test).

In several other groups occupationally exposed to genotoxic substances, we detected a higher increase in DNA single-strand breaks in nonsmokers than in smokers $(12,14)$. Therefore all persons tested in this study were analyzed according to their smoking habits (tables 2-4). No statistically significant differences could be detected between the smokers and nonsmokers in reference groups I and II. In the first analysis, the mean normalized elution rate of the nonsmoking fire fighters who had worked in the contaminated area was significantly higher $[1.60$ ( $\pm 95 \%$ CI 0.24$]$ compared with that of nonsmoking persons from reference group I [1.29 $( \pm 95 \% \mathrm{CI} 0.25)]$ and reference group II [1.16 \pm $\pm 5 \% \mathrm{CI}$ $0.23)](\mathrm{P}<0.05$, U-test). No statistically significant difference in the normalized elution rates could be found between the smoking exposed fire fighters $[1.17( \pm 95 \%$ CI 0.25)] and the smokers from reference groups I [0.97 $( \pm 95 \% \mathrm{Cl} 0.30)]$ and II (1.18 $\pm 95 \% \mathrm{Cl} 0.28)$. However, it should be mentioned that the number of individuals was very small in these subgroups. The mean normalized elution rate was $27 \%$ higher in the total group of smoking and nonsmoking fire fighters when compared with that of reference group II and 38\% higher if only nonsmokers were considered.

No statistically significant correlations ( $t$-statistics of correlation coefficients) were found between the extent of DNA damage and age or alcohol consumption for the individuals in reference groups I and II and for the exposed fire fighters.

An analysis of the elution rates of the exposed fire fighters with respect to the length of exposure could not be performed because almost all of the fire fighters were exposed for $8 \mathrm{~h}$ with the exception of one person who was exposed for $40 \mathrm{~h}$. Nevertheless, it is striking that this particular fire fighter (F2) also showed the highest mean normalized elution rate (2.26) within the group of fire fighters exposed to $o$-nitroanisole.

Twelve of the 16 fire fighters complained of symptoms occurring after their work in the contaminated region (table 2). Skin irritation of the neck or around the mouth was reported by three persons. Three fire fighters complained of burning of the eyes, and four noted an irritation of the upper respiratory tract. Three fire fighters reported nose bleeding and four complained about headache.

\section{Discussion}

An increase in DNA single-strand breaks of $22 \%$ was detected in fire fighters exposed to o-nitroanisole compared with unexposed fire fighters matched for age, cigarette smoking, and alcohol consumption. Liou et al (17) detected an increased number of benzo[a]pyrene diol epoxide-DNA adducts in fire fighters. Therefore an increased number of DNA single-strand breaks in mononuclear blood cells of fire fighters could also be expected, possibly due to skin contact or fumes inhaled during fire fighting. In this study, however, similar numbers of DNA single-strand breaks were detected in fire fighters not exposed to $o$-nitroanisole (reference group I) and persons without any apparent occupational exposure to genotoxic substances (reference group II).

In the second analysis, which was performed $88 \mathrm{~d}$ after the first, the number of DNA single-strand breaks was no longer higher in the exposed fire fighters than in the unexposed fire fighters or the persons from reference group II. Possible mechanisms for the observed decrease in DNA single-strand breaks could be DNA repair or the 
turnover of mononuclear blood cells. Mononuclear blood cells of healthy donors consist of $\mathrm{T}$ lymphocytes (about $81 \%$ ), B lymphocytes (about 3\%), and monocytes (about $16 \%$ ). T lymphocytes consist of a larger long-living subpopulation (at least $90 \%$ ) and of a smaller subpopulation (about 10\%) with half-times of 300-1000 d and less than two weeks, respectively. The majority of B lymphocytes is short-lived (half-time shorter than two weeks), and monocytes leave the vascular system with a mean half-time of $8.4 \mathrm{~h}$ (18). With the use of these numbers, it can be calculated that about $66 \%$ of the mononuclear blood cells present in the first analysis were also present in the second analysis $88 \mathrm{~d}$ later. According to these data the disappearance of DNA single-strand breaks during a period of $88 \mathrm{~d}$ was not likely to be due exclusively to the turnover of mononuclear cells. Therefore the decrease in DNA single-strand breaks seems to have been caused by a slow DNA repair mechanism, which could not remove all of the single-strand breaks induced by $o$-nitroanisole within the $19 \mathrm{~d}$, but was able to reduce DNA single-strand breaks to reference levels $88 \mathrm{~d}$ later.

Little is known about human genotoxic effects of the substances released during the accident. o-Nitroanisole, which represented the main fraction of substances released $(25.3 \%)$, was mutagenic in the Ames test (1) and caused cancer in animals (2). o-Chloronitrobenzene, which represented $1.1 \%$ of the substances released, was mutagenic in the presence of rat liver microsomes as the metabolic activating system (6), and caused tumors in rats (7). 0 -Anisidine, representing $0.6 \%$ of the substances released, caused DNA single-strand breaks in mouse lymphoma cells in the presence of rat liver microsomes (4), and also caused bladder cancer in rats and mice (5).

In earlier studies, we analyzed DNA single-strand breaks in mononuclear blood cells of persons occupationally exposed to putative carcinogens. For nonsmoking workers, compared with referents, the increase in DNA single-strand breaks was found to be $60 \%$ for painters, $70 \%$ for workers exposed to ethylene oxide, and $69 \%$ for metal workers exposed to cutting fluids $(12,14)$. In smokers consuming more than 10 cigarettes per day, $13 \%$ more single-strand breaks could be detected than in nonsmokers (12). In comparison with the results of earlier studies, the mean normalized elution rate of the fire fighters exposed to $o$-nitroanisole was increased to a relatively low extent $38 \%$ in the nonsmoking fire fighters) in comparison with that of the nonsmoking referents. Furthermore, individuals from the aforementioned occupational groups are usually exposed to the substances continuously during their occupational life, whereas the fire fighters were exposed to the accidentally emitted $o$-nitroanisole and other compounds of the mixture for a short period only.
The determination of an equivalent concentration of a well-known genotoxic substance such as ethylene oxide could help one assess the risk for the exposed fire fighters. However, this kind of risk assessment is indirect because it is not known whether DNA damage caused by ethylene oxide or $o$-nitroanisole has similar biological relevance. The detection of DNA single-strand breaks in mononuclear blood cells of persons exposed to ethylene oxide revealed an increase in normalized elution rates of 0.19 if the concentration of ethylene oxide was elevated by $1 \mathrm{mg} \cdot \mathrm{m}^{-3}$ (4-h time-weighted average) (14). Therefore an increase in normalized elution rates by 0.27 , calculated for the fire fighters compared with persons without any apparent occupational exposure to genotoxic substances, would be equivalent to exposure to an ethylene oxide concentration of $1.4 \mathrm{mg} \cdot \mathrm{m}^{-3}$. Human exposure to ethylene oxide concentrations of almost $2 \mathrm{mg} \cdot \mathrm{m}^{-3}$ (occupational exposure limit) may be tolerated during their complete occupational life, whereas the fire fighters were exposed to the accidentally emitted substances for a short period of time. Therefore we estimate only a minor genotoxic hazard for the fire fighters due to their service in the accidentally contaminated area, compared with the genotoxic hazard of other occupational groups. However, these considerations have to be treated with caution since, at present, it is not known whether DNA single-strand breaks or alkali labile sites caused by ethylene oxide or $o$-nitroanisole have similar biological consequences.

\section{References}

1. Chiu CW, Lee LH, Wang CY, Bryan GT. Mutagenicity of some commercially available nitro compounds for Salmonella typhimurium. Mutat Res 1978;58:11-22.

2. National toxicology program: technical report. Fed Regist 1992;57:24806.

3. Department of Transportation. Emergency response guidebook 1987, Washington, DC: US Government Printing Office, 1987.

4. Garberg P, Akerblom EL, Bolcsfoldi G. Evaluation of a genotoxicity test measuring DNA-strand breaks in mouse lymphoma cells by alkaline unwinding and hydroxyapatite elution. Mutat Res 1988;203:155-76.

5. Doull J, Klassen CD, Amdur MD, editors. Casarett and Doull's toxicology. 3rd edition. New York, NY: Macmillan, 1986.

6. Suzuki J, Koyama T, Suzuki S. Mutagenicities of mononitrobenzene derivatives in the presence of norharman. Mutat Res 1983;120:105-10.

7. Weisburger EK, Russfield $\mathrm{AB}$, Homburger $\mathrm{F}$, Weisburger $\mathrm{JH}$ Hoger $\mathrm{E}$, Van Dongen CG, et al. Testing of twenty-one environmental aromatic amines or derivatives for long-term toxicity or carcinogenicity. J Environ Pathol Toxicol 1978;2:32556.

8. Sina JF, Bean CL, Dysart GR, Tay lor VJ, Bradley MO. Evaluation of the alkaline elution/rat hepatocyte assay as a predictor of carcinogenic/mutagenic potential. Mutat Res 1983,113: 357-91.

9. Walles SA, Norppa H, Osterman-Golkar S, Mäki-Paakkanen 
J. Single-strand breaks in DNA of peripheral lymphocytes of styrene-exposed workers. Lyon: International Agency for Research on Cancer, 1988:223-6. IARC scientific publications, no 89.

10. Mäki-Paakkanen J, Walles S, Osterman-Golkar S, Norppa H. Single-strand breaks, chromosome aberrations, sister-chromatid exchanges, and micronuclei in blood lymphocytes of workers exposed to styrene during the production of reinforced plastics. Environ Mol Mutagen 1991;17:27-31.

11. Walles SA, Edling C, Anundi H, Johanson G. Exposure dependent increase in DNA single strand breaks in leucocytes from workers exposed to low concentrations of styrene. Br J Ind Med 1993;50:570-4.

12. Oesch F, Hengstler JG, Fuchs J. Cigarette smoking protects mononuclear blood cells of carcinogen exposed workers from additional work-exposure-induced DNA single-strand breaks. Mutat Res 1984;321:175-85.

13. Hengstler JG, Fuchs, J, Oesch, F, DNA strand breaks and DNA cross-links in peripheral mononuclear blood cells of ovarian cancer patients during chemotherapy with cyclophosphamide/carboplatin. Cancer Res 1992; 52:5622-6.

14. Fuchs J, Wullenweber U, Hengstler JG, Bienfait HG, Hiltl G,
Oesch, F. Genotoxic risk for humans due to a working place exposure to ethylene oxide: remarkable individual differences in susceptibility. Arch Toxicol 1994;68:343-8.

15. Boyum A. Separation of white blood cells. Nature 1964;204:793.

16. Kohn KW, Ewig RAG, Erickson LC, Zwelling, LA. Measurement of strand breaks and cross-links by alkaline elution. In; Friedberg EC, Hanawalt PC, editors. DNA repair. New York, NY: Marcel Dekker, 1980:379-401.

17. Liou SH, Jacobson-Kram D, Poirier MC, Nguyen D, Strickland PT, Tockman MS. Biological monitoring of fire fighters: sister chromatid exchange and polycyclic aromatic hydrocarbon-DNA adducts in peripheral blood cells. Cancer Res 1989;49:4929-35.

18. Athens JW, Weinberg JB, Paraskevas F, Foerster J. Leukocytes - the phagocytic and immunologic systems. In: Lee GR, Bithell TC Foerster J, editors. Wintrobe's clinical hematology. London: Lea \& Febiger, 1993:223-419.

Received for publication: 27 January 1994 